DOI: https://doi.org/10.18485/philologia.2020.18.18.9

UDC: 821.111.09 Chaucer G.

\title{
THREE CHAUCERS: THE MAN, THE TELLER, THE ANTHROPOLOGIST
}

CODRUȚA MIRELA STĂNIȘOARĂ ${ }^{1}$

University of Craiova

Craiova, Romania

Rad se zasniva na istraživanju koje povezuje antropologiju i književnost. Stoga se pristup autora može posmatrati kao interdisciplinaran pristup kojim se želi podstaknuti savremeni čitalac na to da razmišlja o mnogostrukim odgovorima pohranjenim u tekstovima srednjevekovnih autora. Čoserov književni opus, posmatran kroz savremene postmoderne kulturološke i socijalne antropološke teorije, pre svega one koje se odnose na potrošačku kulturu, pokazuje upravo takav pluralizam tumačenja, što omogućava bolje razumevanje sveta i nas samih. Te savremene teorije mogu se posmatrati kao uvod u ponovno čitanje Čosera, i to kroz prizmu antropologije.

Ključne reči: antropologija, književnost, sopstvo, drugi, kulturološka svest, (antropo)čitanje.

\section{CHAUCER, HIS SELVES AND THE OTHERS}

Geoffrey Chaucer has been re-read, refigured and even multiplied into two, three and even four different selves many times by many scholars. Given our advocacy for an alternative reading route to Chaucer and his works, subject to the anthropological approach of the literary text, we will use the idea of Chaucer's selves as it derives from the literary criticism of his works in order to relate them to the central and basic anthropological theme: self and the other.

The idea of writing an article titled Three Chaucers comes from an article in the Medium Aevum Journal, by Norman Klassen, Two Chaucers (Klassen 1999: 22). The author starts from the idea of polarization in terms of critical issues and discussions regarding a Social Chaucer, who gives a remarkable record of a fourteenth century pilgrimage, read in the context of the medieval society he represented, on the one hand, and a kind of a cultural one, on the other.

1 Kontakt podaci (Email): ancasst@gmail.com 
Recent critics of Chaucer, such as Lee Patterson and Paul Strohm, have explored the importance of the idea of social status in his works based on his position in the aristocracy both by profession and by marriage. Paul Strohm looks at Chaucer's work and Chaucer himself as deeply implicated in the urgent social context of the time. By virtue of his connections both with the Court and with the increasingly powerful mercantile class, Chaucer was exposed with a peculiar intensity to what Strohm describes as "the transition from feudalism to capitalism in the fourteenth century" (Strohm 1989: 198), and his work attempts to give a voice to different and competing social outlook. He looks at The Canterbury Tales as if it were the climax of Chaucer's social thinking, reading the work as "a project of representation of the various social groupings and as conciliation between them, in the environment of lessened risk provided by a literary work" (Strohm 1998: 225).

On the contrary such modern scholars as David Wallace with his study that internationalizes Chaucer expresses himself in favour of Chaucer's fascination for experiencing with cultural diversity. In his most recent study, Geoffrey Chaucer: $A$ New Introduction, he suggests a new possible productive route to reading Chaucer and speaks for the first time about "an internationalization of Chaucer [...]. He was a European who spoke English, Italian, French and Latin, while being exposed to Dutch, too, a kind of a 'poly-localities' influence in his life" (Wallace 2017: 48). He travelled from England to Florence, France, Lombardy and Bohemia where he encountered different human types representing different cultures.

In the context of our suggested approach we may look at Chaucer crossing borders as a field researcher does, in a kind of a jump into the others' culture which we may assimilate with the so called "ethnic leap", disclosing an unprecedented self in which the anthropologist overlaps the writer. In Chapter II, Cultural Immersion of his study, Joseph Conrad and the Anthropological Dilemma, John Griffith compares the anthropological fieldwork with the work done by Conrad's characters who make a jump into the unknown which equals with an ethnic leap (Griffith 1995: 47).

We are entitled to believe that in his travels he behaved like a field researcher by assuming a possible parallel with Borislav Malinovski, a famous anthropologist endowed with the artistic gift of a writer. Clifford Geertz claims that only a few anthropologists, Borislav Malinovski being one of them, may be recognized as having a distinctive literary style.

Practically David Wallace is the first scholar who speaks about two Chaucers, one who gives his literary texts the image of univocity and the other of arbitrariness, which lead to two alternative ways of reading him: "These two alternatives [...] persistently give shape to two rather different Chaucers and represent a challenge that might profitably be addressed more explicitly in ethical terms such as Ricoeur's carefully explored notion of 'oneself as another'"' (Wallace 2017: 53).

In his writings, Chaucer seems to divide his own self according to his immediate interests into: Chaucer the pilgrim-narrator, also known as the teller, Chaucer the poet, Chaucer the historian, a stance in which he may be read as the anthropologist. Almost anyone who reads Chaucer becomes aware of at least one duplicity pair: the man and the teller, the civil servant and the poet. 
There is a disparity of Chaucerian criticism regarding Chaucer himself and fictional Chaucer that started with Professor Donaldson's article in which he attempted to show that Chaucer the poet puts on different masks in order to hide himself behind the comic figure of Chaucer the pilgrim. For H. Marshall Leicester Jr., "Chaucer the pilgrim is a complex and sophisticated impersonator who directs us to the roles he plays." (Leicester 1980: 214) In fact, he undertakes several impersonations, hiding under different masks, the ones which suit him best, as in a Venetian carnival.

S. H. Rigby, in Monologic versus Dialogic Chaucer sees two opposite ways of reading Chaucer: "real life observation versus literary convention" (Rigby 1996: 56). Similarly, Chaucer's Canterbury Tales have been refigured many times from a double perspective: as a literary study and as a study of history.

Another group of critics, including Carolyn Dinshaw and Elaine Tuttle Hansen has analysed Chaucer's engagement with gender issues, while Susan Schibanoff, a main voice in her own group identifies ethnic and religious aspects by raising questions regarding the other and about blurring the boundaries of gender and geography. In this view she notes religious aspects in "The Man of Law's Tale" and speaks about Chaucer's non Christian as being the Other (Schibanoff 1996: 59-96).

Starting from the critics' opinions we will reconsider Chaucer and his other entity, that of an anthropologist, by looking at and analysing his selves (the man, the poet, the pilgrim, the historian) in their interdependent relation.

Chaucer the man assumed many roles in his real varied life as courtier, soldier, diplomat, customs collector, royal clerk and Knight of the Shire - as well as, of course, poet, and all them were connected with the court, whose central place will be later kept and acclaimed in the geography of his Canterbury Tales. Diversity plays a key role both in his life and in his works and it will be later accessorized a cultural component.

Geoffrey Chaucer looks at his diverse positions and inherent selves by experiencing them in the same way a field researcher experiences with the culture of the others.

Chaucer's life and literature have to be seen in terms of one another because the knowledge of his person can never be complete, no matter how full the records. In his poems there is no solid biographical information, too.

E. T. Donaldson described him as "a bit absent minded but affable and, one supposes, a very good company, a good-fellow; sagacious and highly-perceptive" (Donaldson 1954: 125), the traits which will be used in composing his literary selves.

From all biographical data we know that two major facts emerge about Chaucer: Chaucer was a bourgeois who made himself a civil servant and a poet of the court who became a pilgrim in The Canterbury Tales. At the surface appearance this is the best resume of his life divided into many selves.

Biographers do not know exactly when or where he was born, the date of his birth is in the 1340s, presumably in London. He grew up in London where his father was a flourishing wine merchant with very good connections with the Court, which marked a good step for Geoffrey Chaucer into a good education and the high society. He became in turns valletus noster and esquire. Also, he had a permanent deputy in the customs, and became justice of the peace and a member of parliament for Kent. From 1391 until 1398 Chaucer was deputy forester of North Petherton Forest Somersetshire where he may have composed most of The Canterbury Tales. 
He used his chances in order to travel several times on the Continent in the king's service on diplomatic and trading missions to Spain, France and Italy which brought him into contact with French and Italian Renaissance poetry in particular with that of Dante Alighieri, Francesco Petrarch and Giovanni Boccaccio. In these foreign territories he developed another self as field researcher and behaved like one of them, he encountered other people and entered their selves, explored them, got his inspiration out of them, experienced cultural diversity, and was finally internationalized. (Wallace 2017: 56)

Chaucer died in 1400 and was buried in the part of the Westminster Abbey, which has become the Poets' Corner.

How does life context relate to the literary one, and how does the variety of life represented in The Canterbury Tales compare with the variety of Chaucer's own life, as well as with the overall variety of life in England at the time?

We should turn to his other self, the writer's, also called the poet, the teller, the storyteller, and look for signs of this variety in his work. That is obvious enough, as there are representatives of many - though not all - sections of late medieval society in The Canterbury Tales. There is almost everyone, from the cook to the knight, a prioress and a pardoner, representing all strata of his contemporary society, although representatives of the very rich and the very poor do not even exist because the higher aristocracy and clergy went on pilgrimages with their own private retinues, while the great mass of the population could not afford to go on pilgrimages at all. He tells us that he is looking at each of the pilgrims in terms of "rank, clothing, physical and moral state and the person's actual reason or being on the pilgrimage" ("estaat", "array", "condicioun" and "cause", respectively (II.35-41; 715-17)). We are dealing with a carefully constructed fiction, in some sense a "type" of character. This applies in varying degrees to all the pilgrims. They are not all equally "individual" or equally "typical", that "individuality within typicality" is simply the counterpart of "variety within unity", a kind of multiculturalism within one and the same culture, which entitles us to re-read it in the light of a cultural and social anthropological approach.

Chaucer gives his characters unique voices, each one different, and each of the twenty-four characters has its own tale. The characters belong to professional groups and have social ranks such as: knight, squire, yeoman, (one group); merchant, clerk, lawyer, franklin (third group); monk, friar, prioress, chaplain, priests, parson (second group); five specified guildsmen, a haberdasher, carpenter, weaver, dyer, tapestry maker (fourth group); the wife of Bath with her professions in matrimony and cloth industry, the shipman, ploughman, miller, manciple, reeve, summoner, pardoner represent different trades. Contrasts and comparisons between groups, as well as within them, might focus on such matters as the presentation of the rich and the poor, or women and men, as well as a whole range of related contrasts between the learned and the ignorant (Chaucer's terms were the "lered" and the "lewed") - the anthropology of craft is visible here.

We should also look at the emphasis on the presence of the court in his life and the way it is present in his poems. In The Canterbury Tales the Knight who is obviously the most symbolic representative of the court occupies a central position: it is the Knight who "by chance" tells the first tale and he is also, of course, idealized. Now we should turn to the other end of the social scale, at the Parson and the Ploughman. These, too, 
are idealized types, but they are also examples of the pious, hard-working and dutiful lower orders. There is an ordained scheme of things in which both high and low classes of society know their respective places.

In The Canterbury Tales the storyteller is actually one of the pilgrims, and we can therefore call him "Chaucer the pilgrim" or "Chaucer the narrator". We find "Chaucer the pilgrim/narrator" talking about himself in II.715-46. The first few lines deal with the rank, appearance and motives of the other pilgrims:

Now have I toold you soothly, in a clause, Th'estaat, th'array, the nombre, and eek the cause

Why that assembled was this compaignye In Southwerk at this gentil hostelrye That highte the Tabard, faste by the Belle. But now is tyme to yow for to telle How that we baren us that ilke nyght, Whan we were in that hostelrie alyght; And after wol I telle of our viage And al the remenaunt of oure pilgrimage. But first I pray yow, of youre curteisye, That ye n'arette it nat my vileynye, Thogh that I pleynly speke in this mateere, To telle yow hir wordes and hir cheere, Ne thogh I speke hir wordes proprely. For this ye knowen al so wel as I, Whoso shal telle a tale after a man, He moot reherce as ny as evere he kan Everich a word, if it be in his charge, Al speke he never so rudeliche and large, Or ellis he moot telle his tale untrewe, Or feyne thyng, or fynde wordes newe. He may nat spare, althogh he were his brother; He moot as wel seye 0 word as another. Crist spak hymself ful brode in hooly writ, And wel ye woot no vileynye is it. Eek Plato seith, whos that kan hym rede, The wordes moote be cosyn to the dede. Also I prey yow to foryeve it me, Al have I nat set folk in hir degree Heere in this tale, as that they sholde stonde. My wit is short, ye may wel understonde. (II. 715-46)

Well, we are likely to have picked up the fact that Chaucer was keen to record what everyone said and looked like, and to do so as accurately as possible ("hir words and hir cheere... as ny as evere he kan"). The other big idea in the passage is fairly obvious too: 
Chaucer is not too sure of himself and keeps apologizing in case he offends anybody or says something stupid ("But first I pray yow, of your curteisye .... Also I prey yow to foryeve it me ... My wit is short, ye may wel understonde"). Again, what we are dealing with is a tension, which in this case is in the narrator himself. On the one hand, there is his claim that he is just observing and being objective; on the other, there is his admission that he may have missed or misjudged some things because he offers himself as a kind of naive reporter because of the pressures on a court poet: that he would deliver his poem in person, that he had to entertain and be interesting, but that he also had to avoid giving offence. Clearly it was wise to appear a little simple, just as it was wise "to tinge everything with 'myrthe"', the sense that everything is basically "fair" and "wel".

While Donaldson considers the writer a distinctive entity, "The poet or the teller is another entity who operates in a realm which is above and subsumes those in which Chaucer the man and Chaucer the pilgrim have their being" (Donaldson 1954:67), we are arguing here that the pilgrim has a double identity: on the one hand he is an impersonation functioning as a mask he puts on in order to give the impression of objectivity or to mock at a society he wouldn't criticise otherwise, and if it is so, it is part of his hypocrisies as a writer. On the other hand, Geoffrey Chaucer purposely makes himself a pilgrim in order to become realistic and convincing. He reports real events in which he is an involved participant; he behaves exactly as if he were a field worker engaged in anthropological research for whom cultural assimilation is possible. Chaucer tries to be impersonal and bewildered at the same time. In the Introduction to his book, Joseph Conrad and the Anthropological Dilemma: "bewildered traveller", John Griffith clearly states that in most of Conrad's writings there is a cultural interest in "primitive" people that relates him to the works of the anthropological writers such as E. B. Tylor, the founder of cultural anthropology. In his approach, Joseph Conrad does not manifest a personal interest though he remains an "emigre", a kind of a cultural outsider himself in his relation with the English people but he is enrolled in the highly manifested concern of the Victorian writers with journeys around the world that coincided with "the philosophical wanderings of anthropological writers" (Griffith 1995: 5).

Chaucer is concerned with the human and social typology of his age, and he remains personally involved in his research, he acts like a cultural insider under the disguise of one of the pilgrims, a traveller-participant engaged in a journey of discovery, adding a new identity to his other selves.

Therefore, if we assume an anthropological point of view we may say that the poet is also in a relationship with a fourth self, the anthropologist's. It is this new undisclosed and unassumed identity of the writer that adds a new dimension to the first one, and it increases complexity of his self in relation with the others, be they his contemporaries, his critics, his readers or his characters. Like Kurtz in Conrad's Heart of Darkness, he launches his self in a journey of self-discovery in the jungle-like medieval society of his time exploring such anthropological themes like gender differences, highlighting female experiences, and varieties of religious beliefs.

Looking at literary texts anthropologically infers a new critical experiment in which the reader may relocate both the writer and the text. From this perspective, Chaucer's self is a fusion of the man with the poet or the teller and the pilgrim together with the hidden stance, that of the performer, or the actor, and it is detectable like this 
at all levels of his literary production. Above them, in an interdependent relation with all his selves there is the anthropologist detectable by modern readers only, in a new approach targeted to track social and cultural anthropological ideas and themes.

\section{CHAUCER AND HIS POSSIBLE (ANTHROPO) READERS}

As modern readers, we find ourselves in the midst of a most recent close reading of the texts, starting from the well-known thematic criticism, socio-political, cultural and historical conditions of literature production and psychoanalysis, known from the histories of literature and anthologies of the academic days to the critical approaches of hermeneutics, and consequently, as teachers, we tailor up our approaches according to these patterns. In light of the deconstructive method of re-reading today we will focus on re-interpreting, re-emphasizing, re-validating meanings of the literary text not approached by the critique so far, namely the literary anthropology, which we may reconsider within the modern critical frame of literature today.

Literary texts can be remote from learners in all sorts of ways - historically, geographically, socially and in terms of life experience. Modern readers may find it impossible to understand medieval or early modern concepts of honour or chastity, for example. Only an anthropological approach could solve this problem.

Perhaps the most satisfying from this point of view is the approach typified by the work of Ricoeur (1981). He sees the process of interpretation in three stages: first comes a thorough and detailed description of the text, its linguistic features and its broader structure, with attention to content as well as to form; this is carried out in an objective manner. Then the actualization of the world of the text follows, that is creating the text by engaging creatively with it in the process of reading. Finally, there is the stage in which the text is reflected on and appropriated existentially and personally.

According to Parkinson, "The work thus draws us into it, distancing us from ourselves, but only to deepen our self-understanding by reflecting aspects of and possibilities for ourselves that we might otherwise never encounter" (Parkinson 2000: 8). The study of literature is set within the broader interdisciplinary context of "cultural studies". Literary value seems to reside somewhere in the relationship between the inner experience of the author, the "truthful" expression of that experience in language, and the sympathetic reception of that expression by the reader.

Literature may also be regarded as writing that fulfils certain socially and culturally approved approaches, and this is especially so with a work written over six hundred years ago. We stress the specificity of an anthropological research of literature that blends together the historical, cultural and social background, the writer's life and writing experience, the readers' selves, their life and cultural experience.

In spite of all these factors that characterize a holistic approach of the author and the text, there is a relative neglect of anthropological approaches to medieval literature.

An anthropological re-reading of The Canterbury Tales by modern readers reveals new characteristics and different levels of text interpretations based on anthropological elements and themes such as: the traveller and his journey seen as a field researcher (Chaucer as a pilgrim and anthropologist), the characters seen as natives, the readers 
cultural immersion, transculturality, the theme of going native, the encounter with the other and his culture (The Middle Ages), alterity and reactions to it, the characters' different voices, professional, social representations and ranks giving contour to an anthropology of craft, female versus male voices, sex and gender issues, and last but not least divergent religious beliefs. There is also Chaucer the pilgrim alternatively seen as a field researcher, as one between the others, oneself seen as another, such new concepts as cultural immersion, cultural displacement, ethnographic behaviour, linguistic anthropology, too.

The encounter with the other and the view of the other are basic anthropological themes very much debated within the modern readers' selves in their imaginary journeys of going native while reading texts dating back to the medieval period of history and literature. Readers suspend their own identity, they go native in order to get cultural awareness and foster awareness of ethnic, religious, and racial issues. They have to read like a native, as we sometimes say. Reading literature from this point of view provides readers with a truly cultural experience and it develops new competences which do not replace the readers' selves but add to and project their selves in a process of transculturation.

The newly acquired cultural competences equip them with culturally-pragmatic and socio-psychological components around which to build effective identities, which will enable their socialization in the target culture and enhance the effectiveness with which they participate in that culture. To use the terminology of social psychologist Erving Goffman (1990) referring to learners' issues, these identities do not replace the readers' selves, but "are the culturally effective and palatable identities which the learners may elect to project or present before the target culture" (Goffman 1990: 111).

David Wallace in his study Geoffrey Chaucer - A New Introduction underlines some of the most innovative features of his work, out of which the blend of genres and strong female voices are ranking first in his advocacy of the uniqueness of Chaucer's writings. Sex and gender issues are anthropological themes, too.

In order to exemplify, in the view of our study, we will resume our approach to sex and gender issues because they are cultural constructs related to a country's historical context, to its ethnic, geographical and religious identities, all of them issues that anthropology as a science deals with. In light of our new approach to re- reading Chaucer anthropologically, we may consider them fundamental literary anthropological themes, present in eighteen stories of The Canterbury Tales, which, analysed through anthropological lenses make the difference in the reader's understanding of the cultural frames of the medieval society on the one hand, and also in the author's and his text's reception over the years by readers of different cultures, on the other.

According to most scholars, this period in the history of humanity was a maledominated one with heterosexual activities loaded with certain violence in the sexual intercourse, directed from men to women. The image of masculinity was one of assault, very often associated in the literature of the time, and in The Canterbury Tales, too, with images of knives and swords brought by men into their erotic relationship. "The Reeve's Tale", for example has been claimed by some scholars to characterize male competitions over women as sexual possessions, or even male revenge. Love making is associated with cutting and piercing, the rape is a frequent act as in "The Wife of Bath Tale". 
This representation of sex aligns with the medieval conventions regarding gender because masculinity in the Middle Ages asserted itself through battles, an ethos and identity specific to courtly love, and its main actor, the knight. On the contrary female sexuality is characterized by consumption in which their sexualized bodies are consumed by men. For women, obedience in the Middle Ages was an axiom as they were always in a submissive position.

A specific characteristic of sexual behaviours is their interaction with social interest. The narrator in Geoffrey Chaucer's "Manciple's Tale" recognizes that medieval women are habitually labelled differently depending on the social class they belong. Therefore, a pure woman is described in derogatory terms while for an aristocratic one he uses a vocabulary of romantic love. Prostitution existed in the Middle Ages and sex outside of the marriage was punished by law, but poor women were more likely in practice to bear the burden of enforcement. Generally, female servants, laundresses or washer women were occupations suspected of sexual deviance, and therefore we may draw a conclusion that in the English medieval society the regulation of prostitution had standards differently applied to different social levels.

Ruth Mazo Karras in her analysis of "The Manciple's Tale" clearly states that, "the tension expressed by Chaucer's Manciple, between women's differences and their similarities, was a pervasive feature of medieval construction of gender" (Karras 2003: 210-229).

More recently, in light of our approach based on the (anthropo) reading of the text, we may bring forward the most recent critical opinions which have called attention to Chaucer's ethnic differences, such as his view of orientalism in "The Squire's Tale", or the portrayal of the Islamic other in "The Man of Law's Tale". Critics have noted Chaucer's attention to multicultural issues regarding the cultural contact between the European Christian and the Islamic world of the Middle West. The religions and ethnic differences are clear in the portraits of the Islamic Sultan and his mother on the one hand, and Custance, an apostolic Christian on the other.

They have recognized the importance of the trinity race-class-gender in mapping a human geography, an attractive field of research for the (anthropo) reader. The perception of the other is evident in the latter tale in which we find blending of the Byzantine, Islamic and Judaic cultures, all of them representing religious others.

\section{CONCLUSIONS}

The possibility of an interdisciplinary approach of literary studies and anthropology started when Clifford Geertz argued for interpreting culture as if it were a text and hereafter he opened the door to interpreting literature as part of culture in an anthropological sense (Geertz 1988: 28). After the cultural movements of the 1960s, literary studies were reconnected with new ideological themes such as: race, gender religion, as part of multiculturalism.

At that time a theoretical critique of culture and ethnography began, and alternatively there have been transformations in anthropology as a science, which followed a new course of interdisciplinary studies with the publications of Bronislav 
Malinovski, an anthropologist who wrote a journal of his field research, later on acclaimed to have literary value, too.

Reflections on the two disciplines complicity have been growing after 1973 with Talal Asad's Anthropology and the Colonial Encounter. A new focus appeared that of textuality, to be found in anthropology and this has led to the borrowing of techniques and theories by ethnographers who experienced such literary devices as intertextuality, juxtaposition, etc. Ethnography is to be seen here as a methodology of anthropology.

Looking at literary texts anthropologically infers a new postmodern experiment in two directions: on the one hand there is the literary criticism, and the reader, on the other. If the former rediscovers possible identities of the writer, his many selves in relation with the readers, the latter relocates the writer and the literary text in his/her own culture in an ethnic leap, which the anthropologist used to do in contact with a new culture. An anthropological approach of the literary text, Chaucer's in our case, may facilitate the process of acculturation when reading foreign literature.

Chaucer is different from other writers because he assigns many roles (many selves) as if he himself were searching for his own identity, and the way he exposes them to his readers has many common elements with the one used by some anthropologists in their field reports, hiding under the mask of the scientists in order not to become too much attached to their new territories of investigation, and eventually to dislocate themselves into them. Finally, we may conclude that there are as many Chaucers as there are readers of Chaucer, however our Chaucer remains one that, in spite of his many selves overlapping, impersonations and disguise under different masks, lets himself open to being read as an author whose text becomes an anthropological journey of self-discovery, one in which his own self gains substance by the detour of the others, be they his characters or his readers.

\section{REFERENCES}

Chaucer, G. 1993. The General Prologue. Norman and London: University of Oklahoma Press, 5-48.

Geertz, C. 1988. Works and Lives. The Anthropologist as Author. Stanford, California: Stanford UP.

Goffman, E. 1990. The Presentation of the Self in Everyday Life. Harmondsworth: Penguin. Griffith, J. 1995. Joseph Conrad and the Anthropological Dilemma. Oxford: Oxford UP.

Klassen, N. 1999. Two Chaucers. Medium Aevum Journal 68(1), 96-104.

Leicester Jr., M. 1980. The Art of Impersonation: A General Prologue to the Canterbury Tales. PMLA 95(2), 213-224.

Mazo Karras, R. 2003. Because the Other Is a Poor Woman She Shall Be Called His Wench: Gender, Sexuality and Social Status in Late Medieval England. In S. Farmer and C. Braun Pasternack (eds.) Gender and Difference in the Middle Ages. Minneapolis: University of Minnesota Press, 210-229.

Parkinson, B. and H. R. Thomas. 2000. Teaching Literature in a Second Language. Edinburgh: Edinburgh UP.

Ricoeur, P. 1981. Hermeneutics and the Human Sciences. New York: Cambridge UP. 
Rigby, S. C. 1996. Chaucer in Context: Society, Allegory and Gender. Manchester: Manchester UP.

Schibanoff, S. 1996. Worlds Apart; Orientalism, Antifeminism, and Heresy in Chaucer's Man of Law's Tale. Exemplaria 8(1), 59-96.

Sell, R. D. 2002. Children's Literature as Communication. Amsterdam and Philadelphia: John Benjamins.

Strohm, P. 1998. A Mixed Commonwealth of Style. In S. Ellis (ed.) Chaucer: The Canterbury Tales. London: Longman, 146-155

Wallace, D. 2017. Geoffrey Chaucer: A New Introduction. 0xford: 0UP.

\section{SUMMARY}

\section{THREE CHAUCERS: THE MAN, THE TELLER, THE ANTHROPOLOGIST}

Based on a research study that connects anthropology with literature our approach should be considered an interdisciplinary one that aims at provoking the modern readers to a multiple-choice response when re-reading medieval authors and their texts. Such postmodern ideas as cultural and social anthropology, the anthropology of craft and the anthropological gift theory of what is called commercial culture, applying to Chaucer and his literary works may lead to a plurality of interpretations that make us better understand his world and our own. They are to be framed as prolegomena to re-reading Chaucer and his works through anthropological lenses.

KEYWORDS: anthropology, literature, self, other, cultural awareness, (anthropo) reading.

ARTICLE INF0:

Original research article

Received: May 1, 2020

Revised: July 20, 2020

Accepted: October 2, 2020 